\title{
DIGLOSIA BAHASA DALAM PELAYANAN OBAT DI APOTEK SITI HADJAR PKU MUHAMMADIYAH TEGAL
}

\author{
Ahmad Sunardi ${ }^{1}$ Agus Susanto ${ }^{2}$ \\ sunardiahmad@yahoo.co.id \\ ${ }^{1,2}$ Politeknik HarapanBersama , \\ Jalan Mataram No 9 Kota Tegal 52142, Indonesia Telp ( 0283 ) 352000
}

\begin{abstract}
Abstrak
Proses komunikasi dalam pelayanan kefarmasian yang melibatkan penutur dan mitra tutur merupakan kegiatan bahasa yang masuk pada ranah sosiolinguistik.Peristiwakontak bahasa yang dilakukan penutur dan mitra tutur pada pelayanan diapotek tidak bisa lepas dari diglosia bahasa. Adapun tujuan penelitian adalah untuk mengetahui diglosia bahasa dalam swamedika di apotek Siti Hadjar PKU MuhammadiyahTegal. Metode penelitian ini menggunakan metode penelitian kualitatif deskriptif. Proses analisis yaitu: reduksi data (data reduction), penyajian data (data display) dan penarikan simpulan (conclusion). Hasil penelitian berdasarkan Data 1 adalahKata-kata yang digunakan oleh pelayan disampaikan dengan kode etik yang normatif. Jawaban ibu pembeli bukan menggunakan bahasa Indonesia seperti yang disampaikan pelayan, tetapi menggunakan bahasa kromo inggil yang dalam bahasa jawa mempunyai kedudukan tertinggi. Data 2 , tidak ada ragam $\mathrm{T}$ atau ragam $\mathrm{R}$, ini karena seumuran atau dalam pelayanan si Pelayan menyampaikan secara biasa, singkat, dan datar sehingga pembeli pun menjawab dengan singkat dan biasa. Data 3, dalam percakapannya menunjukan pelayan menjelaskan secara detail, sabar dan komunikatif. Kata-kata sapaan diungkapkan berkali-kali, menunjukkan mengakui keberadaan lawan bicara.
\end{abstract}

Kata Kunci: Diglosia, Pelayanan Obat, Komunikasi

\section{Pendahuluan}

Kegiatan pelayanan kefarmasian diapotek memerlukan bahasa sebagai alat komunikasi. Dengan bahasa, maka komunikasi antara farmasis dan konsumen dapat tercipta. Dengan bahasa pula, kegiatan pelayanan kefarmasian dapat terlaksanan. ${ }^{[1]}$

Proses komunikasi dalam pelayanan kefarmasian yang melibatkan penutur dan mitra tutur merupakan kegiatan bahasa yang masuk pada ranah sosiolinguistik. Dalam sosiolinguistik, masyarakat sebagai subyek tutur mempunyai peran penting dalam penggunaan bahasa. ${ }^{[2]}$

Terkait dengan peristiwa kontak bahasa yang dilakukan penutur dan mitra tutur pada pelayanan diapotek tidak bisa lepas dari diglosia bahasa. Diglosia adalah suatu situasi bahasa di mana terdapat pembagian fungsional atas varian-varian bahasa atau bahasa-bahasa yang ada di masyarakat. Dalam praktiknya, penggunaan bahasa pada pelayanan kefarmasian yang terjadi diapotek mengalami diglosia ${ }^{[3]}$

Diglosia dalam pelayanan kefarmasian diapotek menarik untuk dikaji. Oleh karena itu, penelitian diglosia bahasa dalam pelayanan obat diapotek penting untuk diteliti. Dalam penelitian ini, apotek Siti Hadjar PKU Muhammadiyah Kota Tegal dijadikan ojek penelitian. Dengan rumrus masalah; Bagaimanakah bentuk diglosia dalam pelayanan obat di apotek Siti Hadjar PKU MuhammadiyahKota Tegal

\section{Metodologi Penelitian}

Metode penelitian ini menggunakan metode penelitian kualitatif. Adapun jenis penelitian ini adalah deskriptif, yaitu mendeskripsikan (menggambarkan) populasi yang diteliti ${ }^{[4]}$ yakni diglosia bahasa dalam pelayanan obatdi apotek Siti Hadjar PKU Muhammadiyahtegal.

Proses analisis dalam penelitian ini terdiri dari tiga fase ${ }^{[5]}$, yaitu: reduksi data (data reduction), penyajian data (data display) dan penarikan simpulan (conclusion). Ini berarti data-data yang telah terkumpul akan dipilah-pilah dan disajikan dengan memberikan analisa sehingga dapat diambil simpulan. 


\section{Hasil Penelitian}

Hasil percakapan antara pembeli dan pelayan di di Apotek Siti Hadjar Klinik Pratama PKU Muhamadiyah Tegal.

\section{a. Data 1}

Konteks: Seorang Ibu-ibu mendatangi pelayanan obat di Apotek Siti Hadjar Klinik Pratama PKU Muhamadiyah Tegal, Asisten Apoteker menyerahkan obat sambil menjelaskan waktu minumnya.

Pelayan: "Sehari sekalinya ini yah bu yah, sesudah makan. Vitaminnya ini sehari sekali bu yah, sesudah makan.

Sehari sekali bu yah sesudah makan".

Pembeli : "Nggeh".

Analisis Diglosia

Dalam percakapan tersebut, diketahui seorang ibu-ibu berumur 40 tahun mendatangi Apotek dan disambut oleh pelayan apotek dengan menjelaskan pengunaan obat sambil menyerahkan obat. Seorang pelayan menyampaikan dengan bahasa yang normatif, menggunakan bahasa Indonesia yang komunikatif, bahasa yang mudah dimengerti dan paling mudah digunakan sehari-hari. Kata-kata yang digunakan oleh pelayan disampaikan dengan kode etik yang normatif, yaitu kata-kata yang pantas sebagai bentuk pelayanan. Katakata "Bu yah" ini menunjukan kata sapa yang memperkuat terhadap keberadaan lawan bicara, dengan kata-kata ini lawan bicara merasa dianggap keberadaannya, merasa disapa, dan merasa diajak bicara, yaitu kata-kata khusus untuk ibu-ibu yang akan mengambil obat.

Dari kata-kata yang diungkapkan oleh pelayan, Ibu pembeli kemudian menjawab "Nggeh". Jawaban ibu pembeli bukan menggunakan bahasa Indonesia seperti yang disampaikan pelayan, tetapi menggunakan bahasa kromo inggil yang dalam bahasa jawa mempunyai kedudukan tertinggi dalam etika percakapan masyarakat Jawa. Jawaban tersebut merupakan penghormatan kepada pelayan, merupakan wujud penghargaan. Dengan adanya jawaban tersebut, yang menurut bahasa jawa mempunyai ragam tinggi, maka ini merupakan bentukmenghargao dan menghormati seseorang bias diungkapkan melalui bahasa.

b. Data 2

Konteks: Seorang pemuda sedang menerima pelayanan obat di di Apotek Siti Hadjar Klinik Pratama PKU Muhamadiyah Tegal".

Pelayan: "Tiga kali sehari setelah makan" (sambil menunjukan obat).

Pembeli: "Iya"

Pelayan: "Tiga kali sehari setelah makan" (sambil menunjukan obat)

Analisis Diglosia

Dari percakapan tersebut pelayan menyampaikan secara langsung "to the point" tentang penggunaan obat tanpa kata sapaan. Pembeli yang sama-sama muda dengan pelayan hanya menjawab "Iya" menunjukan sudah paham apa yang dimaksud oleh pelayan tanpa ada jawaban selanjutnya. Dari percakapan ini tidak ada ragam $\mathrm{T}$ atau ragam $\mathrm{R}$, mungkin karena seumuran atau dalam pelayanan si Pelayan menyampaikan secara biasa, singkat, dan datar sehingga pembeli pun menjawab dengan singkat dan biasa.

Jawaban pembeli tersekesan biasa dan tanpa memberikan penghargaan tinggi terhadap pelayanan si Pelayan, ini menunjukan bahwa sebuah percakapan yang dilakukan oleh sejawat cenderung datar tanpa unsur ragam $\mathrm{T}$ sebagai diglosia dalam berbahasa.

c. Data 3

Konteks: Seorang Kakek mendatangi Apotek untuk mengambul obat, Pelayan langsung menyambut dengan menyerahkan obat dan menjelaskan penggunaannya.

Pelayan: Sehari sekali buat tensi yah pak yah, sesudah makan.

Sehari sekali buat gula sesudah makan yah pak yah.

Yang ini sehari dua kali buat lambung, sebelum makan.

Sehari tiga kali buat pusing yah, sesudah makan yah.

Pembeli: Pokoknya sebelum dan sesudah nggeeh?

Analisis Diglosia

Percakapan tersebut menunjukan pelayan menjelaskan secara detail, sabar 
dan komunikatif. Kata-kata sapaan diungkapkan berkali-kali, menunjukkan mengakui keberadaan lawan bicara. Kata-kaya penegasan agar bisa dimengerti seperti "yah pak yah" ini menunjukan usaha pelayan untuk menyampaikan secara sabar dan penegasan tentang penggunaan obat yang disampaiakn.

Kemudian dari penyampaian tersebut, pembeli menjawab "Pokoknya sebelum dan sesudah nggeh?". Jawaban ini merupakan jawaban penegasan pula, bahwa pembeli sudah jelas terhadap apa yang disampaiakan oleh pelayan. Kata "pokoknya" merupakan simpulan dari apa yang disampaikan oleh pelayan, merupakan penutup jawaban yang tegas dari pembeli namun berbuatan menghargai dan memberikan hormat dengan mungungkapkan kata "nggeh" sebgai ragam $\mathrm{R}$ dalam bahasa Jawa yang pantas untuk diberikan kepada orang yang dihormatinya. Dari percakapan ini menunjukan bahwa diglosia bahasa tidak bias lepas dari percakapan hidup seharihari manusia sebagai makhluk bermoral dan berbudaya bahasa. ${ }^{[6]}$

\section{Kesimpulan}

Dari percakapan pada data 1, Jawaban ibu pembeli bukan menggunakan bahasa Indonesia seperti yang disampaikan pelayan, tetapi menggunakan bahasa kromo inggil yang dalam bahasa jawa mempunyai kedudukan tertinggi dalam etika percakapan masyarakat Jawa. Jawaban tersebut merupakan penghormatan kepada pelayan, merupakan wujud penghargaan. Dengan adanya jawaban tersebut, yang menurut bahasa jawa mempunyai ragam tinggi, maka ini merupakan bentukmenghargao dan menghormati seseorang bias diungkapkan melalui bahasa.

Pada Data 2, Jawaban pembeli tersekesan biasa dan tanpa memberikan penghargaan tinggi terhadap pelayanan si Pelayan, ini menunjukan bahwa sebuah percakapan yang dilakukan oleh sejawat cenderung datar tanpa unsur ragam $\mathrm{T}$ sebagai diglosia dalam berbahasa.
Data 3, pembeli menjawab "Pokoknya sebelum dan sesudah nggeh?". Jawaban ini merupakan jawaban penegasan pula, bahwa pembeli sudah jelas terhadap apa yang disampaiak oleh pelayan. Kata "pokoknya" merupakan simpulan dari apa yang disampaikan oleh pelayan, merupakan penutup jawaban yang tegas dari pembeli namun berbuatan menghargai dan memberikan hormat dengan mungungkapkan kata "nggeh" sebgai ragam $\mathrm{R}$ dalam bahasa Jawa yang pantas untuk diberikan kepada orang yang dihormatinya. Dari percakapan ini menunjukan bahwa diglosia bahasa tidak bias lepas dari percakapan hidup sehari-hari manusia sebagai makhluk bermoral dan berbudaya bahasa $^{\left[{ }^{[7]}\right.}$

\section{Daftar Pustaka}

[1] Alwasilah, A. Chaedar. 1990. Sosiologi Bahasa. Bandung: Angkasa

[2] Nababan, PWJ.,.1993. Sosiolinguistik Suatu Pengantar, Jakarta: Gramedia Pustaka Utama

[3] Chaer, Abdul dan Leonie Agustina. 2004. Sosiolinguistik. Jakarta: Rineka Cipta

http://apotekrakyat.wordpress.com/20 12/05/30/apotek/(diakses 06/02/2017)

[4] Moloeng, Lexy J. 2004. Metode Penelitian Kualitatif. Bandung: PT Remaja Rosda. Karya

[5] Kriyantono, Rachmat. 2010. Teknik praktis riset komunikasi: disertai contoh praktis riset media, public relation, advertising, komunikasi organisaso, komunikasi pemasaran. Jakarta: Kencana

[6] Ruslan, Rosady. 2002. Kiat dan Strategi Kampanye Public Relations. Jakarta: PT Raja Grafindo Persada,

[7] Sumarsono. 2007. Sosiolinguistik. Yogyakarta: Sabda 